\title{
Characterization of clinical isolates of Mycobacterium tuberculosis from indigenous peoples of Colombia
}

\author{
Darío Puerto', Lina Erazo ${ }^{1}$, Angie Zabaleta², Martha I. Murcia ${ }^{3}$, Claudia Llerena², \\ Gloria Puerto ${ }^{1}$ \\ ${ }^{1}$ Grupo de Micobacterias, Dirección de Investigación en Salud Pública, Instituto Nacional de \\ Salud, Bogotá, D.C., Colombia \\ ${ }^{2}$ Grupo de Micobacterias, Dirección Redes en Salud Pública, Instituto Nacional de Salud, \\ Bogotá, D.C., Colombia \\ ${ }^{3}$ Grupo de Micobacterias, Facultad de Medicina, Universidad Nacional de Colombia, Bogotá, \\ D.C., Colombia
}

Introduction: Tuberculosis continues to be a public health priority. Indigenous peoples are vulnerable groups with cultural determinants that increase the risk of the disease.

Objective: To determine molecular epidemiology and phenotypical features and of Mycobacterium tuberculosis isolates from indigenous people in Colombia during the period from 2009 to 2014.

Materials and methods: We conducted an analytical observational study; we analyzed 234 isolates to determine their patterns of sensitivity to antituberculosis drugs and their molecular structures by spoligotyping.

Results: The isolates came from 41 indigenous groups, predominantly the Wayúu (13.10\%) and Emberá Chamí (11.35\%). We found 102 spoligotypes distributed among seven genetic families (37.2\% LAM, 15.8\% Haarlem, 8.1\% T, 3.4\% U, 2.6\% S, 2.1\% X, and 0.9\%, Beijing). The association analysis showed that the non-clustered isolates were related to prior treatment, relapse, orphan spoligotypes, and the Beijing family. The $\mathrm{H}$ family presented an association with the Arhuaco and Camëntsá indigenous groups, the $U$ family was associated with the Wounaan group, and the T family was associated with the Motilón Barí group. Conclusions: This is the first national study on M. tuberculosis characterization in indigenous groups. The study evidenced that diagnosis in indigenous people is late. We described $53 \%$ of orphan patterns that could be typical of the Colombian indigenous population. The high percentage of grouping by spoligotyping (62\%) could indicate cases of active transmission, a situation that should be corroborated using a second genotyping marker. A new Beijing spoligotype (Beijing-like SIT 406) was identified in Colombia.

Received: $26 / 02 / 19$

Accepted: 15/01/19

Published: $16 / 01 / 19$

\section{Citation:}

Puerto D, Erazo LM, Zabaleta A, Murcia MI, Llerena C, Puerto G. Characterization of clinical isolates of Mycobacterium tuberculosis from indigenous peoples of Colombia. Biomédica. 2019;39(Supl.2):78-92. https://doi.org/10.7705/biomedica.v39i3.4318

\section{Corresponding author:}

Gloria Mercedes Puerto, Grupo de Micobacterias, Dirección de Investigación en Salud Pública, Instituto Nacional de Salud, Avenida Calle 26 N 51-20, Zona CAN, Bogotá, D.C., Colombia Telephone: (+571) 2207700 , extension 1244 gpuerto@ins.gov.co

\section{Author contributions:}

Claudia Llerena and Gloria Puerto: Conception and design of the experiments

Darío Puerto, Lina Erazo and Angie Zabaleta:

Performance of the experiments

Darío Puerto, Claudia Llerena, Martha I Murcia and

Gloria Puerto: Data analysis and drafting of the paper

\section{Funding:}

The study was financed jointly by Colciencias and the Colombian Instituto Nacional de Salud (Grant 468-2013).

\section{Conflicts of interest:}

The authors declare that there are no conflicts of interest regarding the contents of this manuscript.
Keywords: Tuberculosis/epidemiology; indigenous population (public health); genotype; molecular epidemiology; drug resistance.

Caracterización de aislamientos clínicos de Mycobacterium tuberculosis de pueblos indígenas de Colombia

Introducción. La tuberculosis es prioridad de salud pública. Los pueblos indígenas son vulnerables debido a los factores culturales determinantes que aumentan el riesgo de tuberculosis.

Objetivo. Determinar la epidemiologia molecular y las características fenotípicas de los aislamientos de Mycobacterium tuberculosis de pueblos indígenas de Colombia entre 2009 y 2014. Materiales y métodos. Se hizo un estudio observacional analítico; se analizaron 234 aislamientos para determinar la sensibilidad a los fármacos antituberculosos y la estructura molecular usando spoligotyping. La información epidemiológica se recolectó utilizando el formato único de vigilancia de micobacterias.

Resultados. Los aislamientos provenían de 41 grupos indígenas, principalmente los wayúu $(13,10 \%)$ y emberá chamí (11,35\%). Se encontraron 102 genotipos distribuidos en siete familias genéticas (37,2 \%, LAM; 15,8 \%, Haarlem; 8,1 \%, T; 3,4 \%, U; 2,6 \%, S; 2,1\%, $X$, y $0,9 \%$, Beijing). El análisis de asociación mostró que los aislamientos no agrupados se asociaron con el tratamiento previo, las recaídas, los genotipos huérfanos y la familia Beijing. La familia $\mathrm{H}$ presentó una asociación con los grupos indígenas arhuaco y camëntŝá, la familia U se asoció con el grupo wounaan y la familia T con el grupo motilón barí. Conclusiones. Este es el primer estudio nacional de caracterización de M. tuberculosis en grupos indígenas. Se evidenció que el diagnóstico en indígenas es tardío, y que 53 \% de los patrones huérfanos podrían ser típicos de la población indígena colombiana. El alto porcentaje de agrupamiento por spoligotyping (62\%) podría indicar casos de transmisión activa, una situación que debe ser corroborada usando un segundo marcador de genotipificación. Se identificó un nuevo genotipo (Beijing-like SIT 406) en Colombia.

Palabras clave: Tuberculosis/epidemiología; población indígena; genotipo; epidemiología molecular; resistencia a medicamentos. 
Tuberculosis continues to be a public health priority worldwide and its control is part of the sustainable development goals established by the United Nations organization (1). The World Health Organization (WHO) estimated that 10.4 million new tuberculosis cases would occur in 2016 (2); in Colombia, 13,871 new tuberculosis cases were registered that same year, of which 840 occurred among indigenous populations (3).

The global "End Tuberculosis Strategy" adopted by WHO as a work approach for member states seeks to provide continuity for tuberculosis control actions after 2015. The strategy considers the protection and promotion of ethics and equity in its principles and fosters differential attention to vulnerable populations including indigenous groups (4). The social and cultural determinants and the immunological factors typical of indigenous peoples are associated with a predisposition for the disease. Risk factors such as overcrowding, malnutrition, and difficulties in accessing healthcare services are linked primarily to the geographic areas that these people inhabit. Additionally, ignorance of the disease has been described (5-7).

According to the Organización Nacional de Indígenas Colombianos, there are 102 indigenous groups in Colombia (8). However, the last national census carried out by the Departamento Administrativo Nacional de Estadística (DANE) registered only 87 indigenous groups; these groups are distributed in 710 reservations located in 27 of the 36 territorial entities of the country (9).

Several studies worldwide have shown high rates of tuberculosis among indigenous peoples, mainly associated with difficulties for accessing health services. The active transmission of Mycobacterium tuberculosis has also been confirmed through molecular epidemiology studies (10-15). The approach outlined in the strategic plan "Colombia libre de tuberculosis, 2010-2015" by the Ministry of Health and Social Protection prioritizes vulnerable populations and favors the recognition of the actual tuberculosis situation in these peoples. The following incidence rates have been reported: More than 200 cases per 100,000 inhabitants for the departments of Cesar and Antioquia, more than 80 cases per 100,000 inhabitants in Nariño and La Guajira, and more than 30 cases per 100,000 inhabitants in Guaviare and Guainía $(16,17)$. These rates are well above the national incidence, which has been approximately 25 cases per 100,000 inhabitants over the last ten years (3).

Classical epidemiology has contributed with important advances in the understanding of the determinants associated with the development of tuberculosis. However, during the last few decades, the use of techniques such as spoligotyping and the implementation of molecular epidemiology have strengthened the study of infectious diseases. At present, associations can be determined between genotypes and the manifestation of multidrug resistance, defined as joint resistance to isoniazid and rifampicin (2). These approaches provide accurate information and increase our understanding of the transmission dynamics of pathologies with a public health impact such as tuberculosis (18).

The objectives of this study were to determine molecular epidemiology and phenotypical features of $M$. tuberculosis isolates from indigenous people in Colombia between 2009 and 2014. 


\section{Materials and methods}

\section{Epidemiological information}

The information (origin of indigenous people, gender, age, occupational profile, possible risk factors, and clinical characterization of tuberculosis) was compiled in an Excel 2013 database. This information was based on 234 unique mycobacterial surveillance forms submitted to the Colombian Instituto Nacional de Salud Mycobacteria Group during the 2009-2014 period by the health secretariats in each department.

These records corresponded to 229 individuals from indigenous groups diagnosed with tuberculosis. Five people contributed two isolates of $M$. tuberculosis at different times. In some cases, the tuberculosis and HIV databases of the Sistema Nacional de Vigilancia en Salud Pública, Sivigila, were consulted to complement the information.

\section{Clinical isolates}

A total of $234 M$. tuberculosis clinical isolates from indigenous people diagnosed with tuberculosis between 2009 and 2014 were obtained from the biobank of the Instituto Nacional de Salud Mycobacteria Group. The cryopreserved isolates were recovered in Löwenstein-Jensen solid medium and incubated at $37^{\circ} \mathrm{C}$ for two to four weeks to obtain bacillary biomass.

\section{Identification of species and drug susceptibility test}

Species identification was performed using the immunochromatography test (TB Ag MPT64 Rapid, Cat Nº 08FK50), which detected the MPT64 protein and was confirmed by spoligotyping. First and second-line drug sensitivity tests were performed using the automated BACTEC MGIT TM $960^{\mathrm{TM}}$ system according to the conditions previously standardized by the Instituto Nacional de Salud Mycobacteria Group.

First-line drug sensitivity tests were performed as follows: $1 \mu \mathrm{g} /$ $\mathrm{ml}$ of rifampicin (R), 0.1 and $0.4 \mu \mathrm{g} / \mathrm{ml}$ of isoniazid $(\mathrm{H}), 1$ and $4 \mu \mathrm{g} / \mathrm{ml}$ of streptomycin (S), and 1 and $7.5 \mu \mathrm{g} / \mathrm{ml}$ of ethambutol (E). In cases with resistance to $\mathrm{H}$ and/or $\mathrm{R}$, the tests were performed as follows: $2.5 \mu \mathrm{g} / \mathrm{ml}$ of kanamycin $(\mathrm{Km}), 1 \mu \mathrm{g} / \mathrm{ml}$ of amikacin $(\mathrm{Am}), 2.5 \mu \mathrm{g} / \mathrm{ml}$ of capreomycin (CM), and $2 \mu \mathrm{g} / \mathrm{ml}$ of ofloxacin (Ofx).

The interpretation was done using the EpiCenter and TB-eXiST software ${ }^{\mathrm{TM}}$ (Becton Dickinson 2009, Springer 2009). The internal quality control of these tests was performed using American Type Culture Collection (ATCC) reference strains and the external control supplied by the Laboratorio Supranacional de Referencia at the Chilean Instituto de Salud Pública de Chile.

\section{Spoligotyping}

The DNA extraction process was performed according to van Soolingen, et al. (19). The spoligotyping analysis was performed according to Kamerbeek, et al. (20). The polymerase chain reaction (PCR) product was hybridized on a commercial membrane (Isogen-LifeScience, The Netherlands). The hybridization results were visualized by chemiluminescence using the ECL Direct ${ }^{\mathrm{TM}}$ commercial kit (Amersham, UK) and developed by exposure to a photosensitive film. DNA from the $M$. tuberculosis $\mathrm{H} 37 \mathrm{Rv}$ and $M$. bovis BCG $\mathrm{P} 3$ reference strains were used as a positive control. 
Spoligotyping results were converted into binary and octal codes for the determination of the genetic family and the corresponding Spoligotype International Type (SIT) code using the SpolDB4 international database of the Institute Pasteur de la Guadeloupe (Pasteur Institute of Guadeloupe) (21). The database of the Colombian INS and previous genotyping studies conducted in the country were also consulted for comparisons with circulating spoligotypes (22-27). We calculated the Hunter and Gaston index to determine the discriminating power of spoligotyping (28).

\section{Statistical analysis}

We conducted a percentage description of the analyzed variables, as well as a bivariate statistical analysis to determine the possible associations between the sociodemographic variables, the sensitivity patterns for antituberculosis drugs, and the spoligotypes and clusters obtained by spoligotyping. We used the chi-square test or the Fisher's exact test with a $95 \%$ confidence interval and a significance of 0.05 using the statistical package Epi Info $7.0^{\mathrm{TM}}$. The analyses were performed for 234 clinical isolates.

\section{Ethical considerations}

All study procedures were approved by the INS Research Ethics Committee. According to the Resolution 8430, 1993, issued by the Colombian Ministry of Health, this study did not require informed consent as all of the samples used were isolates obtained from the biobank of the INS Mycobacteria Group and no personal information from patients was extracted (i.e., they were anonymous samples).

\section{Results}

\section{Sociodemographic characteristics of the indigenous populations}

We analyzed isolates from 41 indigenous groups, predominately from the Wayúu ( $n=30,13.10 \%)$, the Emberá Chamí $(n=26,11.35 \%)$, the Awá $(n=18,7.86 \%)$, the Nasa Páez ( $n=15,6.55 \%)$, and the U'wa ( $n=12,5.24 \%$ ) (tables 1 and 2).

The gender distribution showed that $51.09 \%(n=117)$ of the study population was male and $48.91 \%(n=112)$ was female. The age ranged from three months to 100 years. The age subgroups were 0 to 4 years, $5.68 \%(n=13) ; 5$ to 14 years, $5.68 \%(n=13) ; 15$ to 29 years, $29.7 \%(n=68) ; 30$ to 44 years, $25.8 \%$ $(n=59) ; 45$ to 59 years, $16.59 \%(n=38)$, and 60 years or over, $16.59 \%(n=38)$.

\section{Occupational profile and possible risk factors}

The most frequent occupations were homemaker $(n=63,27.51 \%)$ and farmer $(n=50,21.83 \%)$. Other occupations, such as artisan, shaman, botanist, and rancher, were less frequent. The possible risk conditions associated with the development of tuberculosis are described in table 3.

\section{Clinical and phenotypical characterization of the isolates}

Pulmonary tuberculosis was present in $96.94 \%$ ( $n=222$ ) of the cases, whereas extrapulmonary tuberculosis was present in only $3.06 \%(n=7)$ of the cases; $83.84 \%(n=192)$ of the individuals were classified as new cases, $10.91 \%(n=25)$ were previously treated, and $5.24 \%(n=12)$ had no recorded data available. Of the previously treated cases, $32 \%(n=8)$ were relapses, $8 \%(n=2)$ were failures, and $60 \%(n=15)$ were cases in which a category could not be established. Three people $(1.31 \%)$ were recorded as deceased due to tuberculosis. 
Table 1. Indigenous groups identified and number of persons who contributed isolates ( $n=229 ; 100 \%)$

\begin{tabular}{lcc|lll}
\hline Indigenous people & $\mathbf{n}$ & $\%$ & Indigenous people & $\mathbf{n}$ & $\%$ \\
\hline Wayúu & 30 & 13.10 & Yukpa & 3 & 1.31 \\
Emberá Chamí & 26 & 11.35 & Zenú & 3 & 1.31 \\
Awá & 18 & 7.86 & Amorúa & 2 & 0.87 \\
Nasa Páez & 15 & 6.55 & Hitnu & 2 & 0.87 \\
U'wa & 12 & 5.24 & Kogui-Malayo-Arhuaco & 2 & 0.87 \\
Arhuaco & 8 & 3.49 & Pastos & 2 & 0.87 \\
Motilón Barí & 8 & 3.49 & Siona & 2 & 0.87 \\
Wounaan & 8 & 3.49 & Cocama & 1 & 0.44 \\
Emberá Katío & 7 & 3.06 & Desano & 1 & 0.44 \\
Tikuna & 6 & 2.62 & Ennaka & 1 & 0.44 \\
Guahibo & 5 & 2.18 & Guambiano & 1 & 0.44 \\
Nukak Makú & 4 & 1.75 & Guanano & 1 & 0.44 \\
Emberá & 4 & 1.75 & Kankuamo & 1 & 0.44 \\
Inga & 4 & 1.75 & Misak & 1 & 0.44 \\
Sikuani & 4 & 1.75 & Mokana & 1 & 0.44 \\
Tucano & 4 & 1.75 & Piapoco & 1 & 0.44 \\
Camëntśá & 3 & 1.31 & Puinave & 1 & 0.44 \\
Cubeo & 3 & 1.31 & Quillacinga & 1 & 0.44 \\
Guayabero & 3 & 1.31 & Yagua & 1 & 0.44 \\
Kogui & 3 & 1.31 & Yuco & 1 & 0.44 \\
Panare & 3 & 1.31 & ND & 22 & 9.61 \\
\hline
\end{tabular}

ND: No data

Table 2. Distribution of indigenous groups per department

\begin{tabular}{|c|c|c|c|c|}
\hline Departament & Indigenous settlement & $\mathbf{n}$ & Total & $\%$ \\
\hline Amazonas & $\begin{array}{l}\text { ND } \\
\text { Tikuna } \\
\text { Cocama } \\
\text { Yagua }\end{array}$ & $\begin{array}{l}5 \\
5 \\
1 \\
1\end{array}$ & 12 & 5,2 \\
\hline Antioquia & Emberá Katío & 1 & 1 & 0,4 \\
\hline Arauca & $\begin{array}{l}\text { Guahibo } \\
\text { Hitnu } \\
\text { ND } \\
\text { Sikuani } \\
\text { U'wa } \\
\text { Piapoco }\end{array}$ & $\begin{array}{l}2 \\
2 \\
2 \\
1 \\
1 \\
1\end{array}$ & 9 & 3,9 \\
\hline Atlántico & Mokana & 1 & 1 & 0,4 \\
\hline Boyacá & U wa & 7 & 7 & 3,1 \\
\hline Caldas & $\begin{array}{l}\text { Emberá chamí } \\
\text { Tikuna }\end{array}$ & $\begin{array}{l}2 \\
1\end{array}$ & 3 & 1,3 \\
\hline Casanare & Amorúa & 2 & 2 & 0,9 \\
\hline Cauca & $\begin{array}{l}\text { Nasa Páez } \\
\text { Guambiano } \\
\text { Misak }\end{array}$ & $\begin{array}{r}11 \\
1 \\
1\end{array}$ & 13 & 5,7 \\
\hline Cesar & $\begin{array}{l}\text { Arhuaco } \\
\text { Wayúu } \\
\text { Kankuamo } \\
\text { ND } \\
\text { Yuco } \\
\text { Yukpa }\end{array}$ & $\begin{array}{l}7 \\
2 \\
1 \\
2 \\
1 \\
3\end{array}$ & 16 & 7 \\
\hline Chocó & $\begin{array}{l}\text { Emberá } \\
\text { Emberá chamí } \\
\text { Emberá Katío }\end{array}$ & $\begin{array}{l}3 \\
2 \\
1\end{array}$ & 6 & 2,6 \\
\hline
\end{tabular}




\begin{tabular}{|c|c|c|c|c|}
\hline Córdoba & $\begin{array}{l}\text { Emberá Katío } \\
\text { Zenú }\end{array}$ & $\begin{array}{l}3 \\
3\end{array}$ & 6 & 2,6 \\
\hline Cundinamarca & Emberá & 1 & 1 & 0,4 \\
\hline Guainía & $\begin{array}{l}\text { ND } \\
\text { Puinave }\end{array}$ & $\begin{array}{l}3 \\
1\end{array}$ & 4 & 1,7 \\
\hline Guaviare & $\begin{array}{l}\text { Nukak Makú } \\
\text { Guayabero } \\
\text { Panare } \\
\text { Tucano }\end{array}$ & $\begin{array}{l}4 \\
3 \\
3 \\
2\end{array}$ & 12 & 5,2 \\
\hline Huila & Nasa Páez & 2 & 2 & 0,9 \\
\hline La Guajira & Wayúu & 28 & 28 & 12,2 \\
\hline Magdalena & $\begin{array}{l}\text { Kogui } \\
\text { Kogui-Malayo- Arhuaco } \\
\text { Arhuaco } \\
\text { Ennaka }\end{array}$ & $\begin{array}{l}3 \\
2 \\
1 \\
1\end{array}$ & 7 & 3,1 \\
\hline Meta & $\begin{array}{l}\text { ND } \\
\text { Sikuani } \\
\text { Nasa Páez }\end{array}$ & $\begin{array}{l}5 \\
3 \\
1\end{array}$ & 9 & 3,9 \\
\hline Nariño & $\begin{array}{l}\text { Awá } \\
\text { Pastos } \\
\text { Inga } \\
\text { Quillacinga } \\
\text { ND }\end{array}$ & $\begin{array}{r}18 \\
2 \\
1 \\
1 \\
1\end{array}$ & 23 & 10 \\
\hline Norte de Santander & $\begin{array}{l}\text { Motilon Barí } \\
\text { U'wa }\end{array}$ & $\begin{array}{l}5 \\
3\end{array}$ & 8 & 3,5 \\
\hline Putumayo & $\begin{array}{l}\text { Camëntŝá } \\
\text { Inga } \\
\text { ND } \\
\text { Siona }\end{array}$ & $\begin{array}{l}3 \\
2 \\
1 \\
2\end{array}$ & 8 & 3,5 \\
\hline Quindío & Emberá chamí & 5 & 5 & 2,2 \\
\hline Risaralda & $\begin{array}{l}\text { Emberá chamí } \\
\text { ND }\end{array}$ & $\begin{array}{r}17 \\
2\end{array}$ & 19 & 8,3 \\
\hline Santander & $\begin{array}{l}\text { Motilon Barí } \\
\text { U wa } \\
\text { Inga }\end{array}$ & $\begin{array}{l}3 \\
1 \\
1\end{array}$ & 5 & 2,2 \\
\hline Valle del Cauca & $\begin{array}{l}\text { Wounaan } \\
\text { ND } \\
\text { Emberá chamí } \\
\text { Nasa Páez }\end{array}$ & $\begin{array}{l}8 \\
2 \\
1 \\
1\end{array}$ & 12 & 5,2 \\
\hline Vaupés & $\begin{array}{l}\text { Cubeo } \\
\text { Tucano } \\
\text { Desano } \\
\text { Guanano }\end{array}$ & $\begin{array}{l}3 \\
2 \\
1 \\
1\end{array}$ & 7 & 3,1 \\
\hline Vichada & Guahibo & 3 & 3 & 1,3 \\
\hline Total & & 229 & 229 & 100 \\
\hline
\end{tabular}

ND: No data

${ }^{*}$ Two pregnant individuals and one individual with chronic obstructive pulmonary disease ** 96 (41.7\%) were HIV-negative and 127 (55.5\%) had no data on HIV status. 
Table 3. Risk factors for tuberculosis identified in the study population

\begin{tabular}{lrrlrr}
\hline Risk factor & $\mathbf{n}$ & \multicolumn{1}{c}{$\%$} & Vulnerable condition & $\mathbf{n}$ & $\%$ \\
\hline Malnutrition & 28 & 12.2 & Schoolchildren & 18 & 7.9 \\
Pregnancy & 6 & 2.6 & Displaced & 13 & 5.7 \\
Diabetes & 1 & 0.4 & Homeless & 1 & 0.4 \\
HIV-positive $^{* *}$ & 6 & 2.6 & Border population & 14 & 6.1 \\
Drug dependence & 1 & 0.4 & & & \\
ND & 187 & 81.8 & ND & 183 & 79.9 \\
Total & 229 & & Total & 229 & \\
\hline
\end{tabular}

ND: No data

${ }^{*}$ Two pregnant individuals and one individual with chronic obstructive pulmonary disease

** 96 (41.7\%) were HIV-negative and 127 (55.5\%) had no data on HIV status.

The 234 positive cultures were recovered from the following clinical samples: Sputum, $82.1 \%(n=192)$; gastric aspirate, $7.7 \%(n=18)$; secretion with no origin identified, $3 \%(n=7)$; biopsy lymph node, $2.1 \%(n=5)$; bronchoalveolar lavage, $1.7 \%$ $(n=4)$; cerebrospinal fluid, $0.9 \%(n=2)$, and ascitic fluid, peritoneal fluid, and pleural fluid, $1.3 \%(n=3)$. No information was recorded for $1.3 \%(n=3)$ of the samples.

\section{Bacilloscopy}

A total of $26.5 \%$ ( $n=62)$ of the cases were positive in the bacilloscopy $(B K+), 23.5 \%(n=55)$ were $B K++$, and $19.2 \%(n=46)$ were $B K+++$, of which $15.2 \%(n=7)$ corresponded to minors (3 to 14 years old). The negative BK samples corresponded to $19.2 \%(n=45)$ of the cases, and no information was recorded for $11.1 \%(n=26)$ of the samples.

All clinical samples had a positive culture on the Löwenstein-Jensen solid medium. Mycobacterium tuberculosis complex identification was positive in all cases.

\section{Drug resistance test}

Of the 234 isolates received, five people contributed two isolates at different times. Only one isolate from each of these cases was considered for the sensitivity profiles.

In total, 192 cases were classified as new cases. Of these, sensitivity test results were obtained for $98.44 \%(n=189) ; 91 \%(n=172)$ of them were sensitive to all the tested first-line drugs, and $8.9 \%(n=17)$ presented resistance to at least one of the drugs tested. Of the 189 isolates analyzed, $3.17 \%(n=6)$ were multidrug resistant. Of the previously treated cases $(n=25)$, $64 \%(n=16)$ were sensitive to all tested first-line drugs and $36 \%(n=9)$ were resistant to at least one drug tested. Of the 25 isolates analyzed, $12 \%(n=3)$ was multidrug resistant. Of the cases without classification based on a previous history of treatment $(n=12), 91.66 \%(n=11)$ were sensitive to all firstline drugs, and the remaining case was multidrug resistant (8.33\%).

The multidrug resistant isolates came from the indigenous groups Emberá Chamí ( $n=3)$, Emberá $(n=3)$, Awá $(n=1)$ and the samples without data $(n=2)$. All cases that showed resistance to $\mathrm{H}$ and/or $\mathrm{R}$ were also evaluated with second-line drugs, although none presented resistance.

\section{Spoligotyping}

All isolates included in the study $(\mathrm{n}=234)$ were confirmed as $M$. tuberculosis by spoligotyping. No circulation of other members of the $M$. tuberculosis complex was detected; 164 isolates were distributed in seven 
genetic families: Latin American-Mediterranean (LAM, 37.2\%, $n=87$ ), Haarlem $(H, 15.8 \%, n=37), T(8.1 \%, n=19), U(3.4 \%, n=8), S(2.6 \%, n=6), X(2.1 \%$, $\mathrm{n}=5)$, and Beijing $(0.9 \%, \mathrm{n}=2)$; a total of $29.9 \%$ of the isolates showed orphan spoligotype patterns for genetic families $(n=70)$.

Out of 234 isolates, 102 spoligotypes were identified, of which $47.1 \%$ $(n=48)$ were previously described in the SpolDB4 database (table 4) and $52.9 \%(n=54)$ were orphan spoligotypes (Supplementary table 1).

Table 4. Distribution of the spoligotypes found in the isolates characterized by spoligotyping $(\mathrm{n}=234 ; 100 \%)$

\begin{tabular}{|c|c|c|c|c|c|c|c|}
\hline Family & SIT & $\mathbf{n}$ & $\%$ & Family & SIT & $\mathbf{n}$ & $\%$ \\
\hline Orphans* & NA & 70 & 29.9 & Beijing-like ${ }^{\star *}$ & 406 & 1 & 0.4 \\
\hline LAM9 & 42 & 33 & 14.1 & $\mathrm{H} 1$ & 610 & 1 & 0.4 \\
\hline LAM2 & 17 & 18 & 7.7 & $\mathrm{H} 3$ & 75 & 1 & 0.4 \\
\hline Harleem1 & 62 & 14 & 6.0 & $\mathrm{H} 3^{* *}$ & 418 & 1 & 0.4 \\
\hline Harleem3 & 50 & 13 & 5.6 & $\mathrm{H} 3^{\star \star}$ & 615 & 1 & 0.4 \\
\hline $\mathrm{T} 1$ & 53 & 8 & 3.4 & LAM2 & 172 & 1 & 0.4 \\
\hline LAM5 & 93 & 7 & 3.0 & LAM2 & 1661 & 1 & 0.4 \\
\hline U (LAM3?) & 106 & 6 & 2.6 & LAM3 & 33 & 1 & 0.4 \\
\hline LAM4 & 60 & 4 & 1.7 & LAM3 & 130 & 1 & 0.4 \\
\hline $\mathrm{S}$ & 34 & 4 & 1.7 & LAM6 $^{* *}$ & 1768 & 1 & 0.4 \\
\hline $\mathrm{T} 2$ & 118 & 4 & 1.7 & LAM9 & 388 & 1 & 0.4 \\
\hline LAM $^{* *}$ & 1691 & 3 & 1.3 & LAM9 & 509 & 1 & 0.4 \\
\hline LAM9 & 162 & 3 & 1.3 & LAM9 $^{* *}$ & 1074 & 1 & 0.4 \\
\hline Harleem1 & 47 & 2 & 0.9 & LAM9 $^{* *}$ & 1530 & 1 & 0.4 \\
\hline Harleem1 & 727 & 2 & 0.9 & $S^{\star *}$ & 1253 & 1 & 0.4 \\
\hline Harleem2 & 2 & 2 & 0.9 & $\mathrm{~S}^{* *}$ & 1938 & 1 & 0.4 \\
\hline LAM1 & 20 & 2 & 0.9 & $\mathrm{~T} 1^{* *}$ & 278 & 1 & 0.4 \\
\hline LAM2-LAM4 & 194 & 2 & 0.9 & $\mathrm{~T} 1^{* *}$ & 628 & 1 & 0.4 \\
\hline LAM9 & 150 & 2 & 0.9 & $\mathrm{~T} 1(\mathrm{Tv})^{* *}$ & 159 & 1 & 0.4 \\
\hline LAM9 & 1535 & 2 & 0.9 & $\mathrm{~T} 2$ & 848 & 1 & 0.4 \\
\hline LAM9 & 1933 & 2 & 0.9 & $\mathrm{~T} 2$ & 1355 & 1 & 0.4 \\
\hline $\mathrm{T} 2^{* \star}$ & 52 & 2 & 0.9 & $\mathrm{U}$ & 160 & 1 & 0.4 \\
\hline $\mathrm{X} 1$ & 217 & 2 & 0.9 & $U^{* *}$ & 1451 & 1 & 0.4 \\
\hline X3 & 91 & 2 & 0.9 & $\mathrm{x} 2$ & 137 & 1 & 0.4 \\
\hline Beijing-like & 190 & 1 & 0.4 & & & & \\
\hline
\end{tabular}

Tv: Tuscany variant; SIT: Spoligotype International Type

${ }^{*}$ Orphan spoligotypes are described in Appendix 3.

** Spoligotypes reported for the first time in Colombia

Out of the spoligotypes described in the study, 62\% $(n=144)$ had not been reported in previous genotyping studies in Colombia; the spoligotype Beijinglike SIT 406 was of particular interest.

When we compared the proportion of spoligotypes found with the INS database and the information reported in Colombia, we established that the spoligotypes with the greatest circulation among the indigenous population were LAM 9 SIT42, H1 SIT62, H3 SIT50, T1 SIT53, and H1 SIT727.

\section{Clustering by spoligotyping and variable association analysis}

The similarity dendrogram showed the presence of 30 clusters consisting of two to 37 isolates for a total of 162 isolates, while 72 isolates were not clustered (Supplementary figure 1).

Non-clustered isolates were associated with being a previously treated patient $(p=0.011)$, relapse $(p=0.039)$, orphan spoligotypes $(p=<0.001)$, and belonging to the Beijing family ( $p=0.014$ ) (table 5 ). 
The analysis showed an association between the T family $(p=0.018)$ and the $X$ family $(p=0.022)$ for resistance to antituberculosis drugs (table 6$)$. Conversely, an association was detected between the failure of treatment $(p=0.005)$ and the presence of multidrug resistance. The $S(p=0.010)$ and $X$ families $(p=0.007)$ were associated with multidrug resistance. No significant association was found between belonging to a particular indigenous group and drug resistance (table 7).

Table 5. Bivariate analyses of sociodemographic variables and genetic families identified by spoligotyping

\begin{tabular}{|c|c|c|c|c|c|c|c|}
\hline \multirow{3}{*}{ Variables } & & \multicolumn{4}{|c|}{ Clustering } & \multirow{3}{*}{ Total } & \multirow{3}{*}{$\mathbf{p}^{*}$} \\
\hline & & \multicolumn{2}{|c|}{ Yes } & \multicolumn{2}{|c|}{ No } & & \\
\hline & & $\mathbf{n}$ & $\%$ & $\mathbf{n}$ & $\%$ & & \\
\hline \multirow[t]{2}{*}{ Gender } & Male & 84 & 70 & 36 & 30 & 120 & Ref \\
\hline & Female & 78 & 68.4 & 36 & 31.6 & 114 & $0.794^{\star *}$ \\
\hline \multirow[t]{5}{*}{ Age (years) } & 0 to 4 & 11 & 73.3 & 4 & 26.7 & 15 & $1,000^{*}$ \\
\hline & 5 to 14 & 11 & 84.6 & 2 & 15.4 & 13 & $0.514^{*}$ \\
\hline & 15 to 44 & 93 & 72.1 & 36 & 27.9 & 129 & Ref \\
\hline & 45 to 59 & 23 & 59 & 16 & 41 & 39 & $0.120^{* *}$ \\
\hline & $\geq 60$ & 24 & 63.2 & 14 & 36.8 & 38 & $0.290^{* *}$ \\
\hline \multirow[t]{6}{*}{ Treatment } & New & 140 & 73.7 & 50 & 26.3 & 190 & Ref \\
\hline & PT & 7 & 43.8 & 9 & 56.2 & 16 & $0.011^{\star *}$ \\
\hline & Relapse & 3 & 37.5 & 5 & 62.5 & 8 & $0.039^{*}$ \\
\hline & Failure & 2 & 66.7 & 1 & 33.3 & 3 & $1,000^{*}$ \\
\hline & Deceased & 2 & 66.7 & 1 & 33.3 & 3 & $1,000^{*}$ \\
\hline & ND & 8 & 57.1 & 6 & 42.9 & 14 & $0.181^{* *}$ \\
\hline \multirow[t]{2}{*}{ MDR } & Yes & 8 & 66.7 & 4 & 33.3 & 12 & $1,000^{*}$ \\
\hline & No & 154 & 69.4 & 68 & 30.6 & 222 & Ref \\
\hline \multirow[t]{8}{*}{ Genetic families } & LAM & 78 & 89.7 & 9 & 10.3 & 87 & Ref \\
\hline & $\mathrm{H}$ & 33 & 89.2 & 4 & 10,821 & 37 & $1,000^{*}$ \\
\hline & $\mathrm{T}$ & 14 & 73.7 & 5 & 26.3 & 19 & $0.126^{\star *}$ \\
\hline & $U$ & 6 & 75 & 2 & 25 & 8 & $0.231^{*}$ \\
\hline & $S$ & 4 & 66.7 & 2 & 33.3 & 6 & $0.147^{\star}$ \\
\hline & $x$ & 4 & 80 & 1 & 20 & 5 & $0.445^{\star}$ \\
\hline & Beijing & 0 & 0 & 2 & 100 & 2 & $0.014^{*}$ \\
\hline & Orphans & 23 & 32.9 & 47 & 67.1 & 70 & $<0.001^{* *}$ \\
\hline
\end{tabular}

PT: Previously treated; ND: No data; Ref: Reference value

* Fisher's exact test

${ }^{* *}$ Chi-squared test; confidence level: $95 \%$

Table 6. Bivariate analysis of genetic families identified by spoligotyping with first-line drug resistance

\begin{tabular}{lrrrrrr}
\hline \multirow{2}{*}{ Family } & \multicolumn{9}{c}{ Susceptibility pattern } & & \\
\cline { 2 - 5 } & \multicolumn{2}{c}{ Resistant } & \multicolumn{2}{c}{ Sensitive } & Total & $\mathbf{p}^{*}$ \\
\cline { 1 - 4 } Orphans & 7 & 10 & 63 & 90 & 70 & 0.111 \\
T & 6 & 31.6 & 13 & 68.4 & 19 & 0.018 \\
LAM & 3 & 3.5 & 84 & 96.6 & 87 & Ref \\
Haarlem & 2 & 5.4 & 35 & 94.6 & 37 & 0.634 \\
X & 2 & 40 & 3 & 60 & 5 & 0.022 \\
Beijing & 1 & 50 & 1 & 50 & 2 & 0.088 \\
U & 1 & 12.5 & 7 & 87.5 & 8 & 0.301 \\
S & 0 & 0 & 6 & 100 & 6 & 1.000 \\
\hline
\end{tabular}

* Fisher's exact test, confidence level: $95 \%$ 
Table 7. Bivariate analyses of variables associated with multidrug resistance

\begin{tabular}{|c|c|c|c|c|c|c|c|}
\hline \multirow{3}{*}{ Variables } & & \multicolumn{4}{|c|}{ Multidrug resistance } & \multirow{3}{*}{ Total } & \multirow{3}{*}{$\mathbf{p}^{\star}$} \\
\hline & & \multicolumn{2}{|c|}{ Yes } & \multicolumn{2}{|c|}{ No } & & \\
\hline & & $\mathbf{n}$ & $\%$ & $\mathbf{n}$ & $\%$ & & \\
\hline \multirow[t]{2}{*}{ Gender } & Male & 6 & 5 & 114 & 95 & 120 & Ref \\
\hline & Female & 6 & 5.3 & 108 & 94.7 & 114 & $0.927^{\star *}$ \\
\hline \multirow[t]{5}{*}{ Age (years) } & 0 to 4 & 1 & 6.7 & 14 & 93.3 & 15 & $0.545^{\star}$ \\
\hline & 5 to 14 & 0 & 0 & 13 & 100 & 13 & $1,000^{*}$ \\
\hline & 15 to 44 & 6 & 4.7 & 123 & 95.3 & 129 & Ref \\
\hline & 45 to 59 & 3 & 7.7 & 36 & 92.3 & 39 & $0.435^{\star *}$ \\
\hline & $\geq 60$ & 2 & 5.3 & 36 & 94.7 & 38 & $1,000^{* *}$ \\
\hline \multirow[t]{6}{*}{ Treatment } & New & 7 & 3.68 & 183 & 96.32 & 190 & Ref \\
\hline & PT & 1 & 6.25 & 15 & 93.75 & 16 & $0.482^{*}$ \\
\hline & Relapse & 1 & 12.5 & 7 & 87.5 & 8 & $0.285^{*}$ \\
\hline & Failure & 2 & 66.67 & 1 & 33.33 & 3 & $0.005^{\star}$ \\
\hline & Deceased & 1 & 33.33 & 2 & 66.67 & 3 & $0.120^{*}$ \\
\hline & ND & 0 & 0 & 14 & 100 & 14 & $1,000^{*}$ \\
\hline \multirow[t]{8}{*}{ Genetic families } & LAM & 1 & 1.15 & 86 & 98.85 & 87 & Ref \\
\hline & $\mathrm{H}$ & 1 & 2.70 & 36 & 97.30 & 37 & $0.509^{*}$ \\
\hline & $\mathrm{T}$ & 2 & 10.53 & 17 & 89.47 & 19 & $0.082^{*}$ \\
\hline & $U$ & 1 & 12.5 & 7 & 87.5 & 8 & $0.162^{*}$ \\
\hline & $\mathrm{S}$ & 2 & 33.3 & 4 & 66.7 & 6 & $0.010^{*}$ \\
\hline & $x$ & 2 & 40 & 3 & 60 & 5 & $0.007^{*}$ \\
\hline & Beijing & 1 & 50 & 1 & 50 & 2 & $0.447^{*}$ \\
\hline & Orphans & 2 & 2.9 & 68 & 97.1 & 70 & $0.586^{*}$ \\
\hline \multirow[t]{5}{*}{ Indigenous groups } & Emberá Chamí & 7 & 25 & 21 & 75 & 28 & Ref \\
\hline & Emberá & 2 & 50 & 2 & 50 & 4 & $0.557^{\star}$ \\
\hline & Awá & 1 & 5.6 & 17 & 94.4 & 18 & $0.124^{*}$ \\
\hline & Camëntŝá & 1 & 33.3 & 2 & 66.7 & 3 & $1.000^{*}$ \\
\hline & Wounaan & 1 & 12.5 & 7 & 87.5 & 8 & $0.651^{*}$ \\
\hline
\end{tabular}

PT: Previously treated; ND: No data; Ref: Reference value

${ }^{*}$ Fisher's exact test;

${ }^{* *}$ Chi-squared test, confidence level: $95 \%$

The association of the $\mathrm{H}$ family was significant for the Arhuaco $(p=0.012)$ and Camëntsá $(p=0.033$ ) indigenous groups. The $U$ family was associated with the Wounaan $(p=0.014)$ group, and the $T$ family was associated with the Motilón Barí $(p=0.002)$ group (data not presented).

\section{Discussion}

Indigenous peoples are among the vulnerable groups defined by the WHO and the Colombian Programa Nacional de Control de Tuberculosis and they are one of the population groups with the highest morbidity and mortality rates associated with tuberculosis (16). According to Cardona, et al. (6), some of the factors associated with this vulnerability involve inherent characteristics of these populations, such as their nomadic condition, their settlement in rural areas that hinders timely access to medical services, and the low adherence to the antituberculosis treatment observed in these population groups.

The number of tuberculosis cases recorded in this study represented $5.6 \%$ of the total tuberculosis cases in the indigenous population of Colombia according to the Sivigila reports from 2009 to 2014 ( $n=4,205)$. In the country, especially in indigenous areas, the most accessible diagnostic method is bacilloscopy (89.5\% of tuberculosis cases for 2015) (3) instead of culture. The clinical isolates in this study were recovered from these cultures for the characterization of drug sensitivity and molecular epidemiology analyses. 
A progressive increase of more than 13.4-fold was observed in the number of cultures sent to the INS from indigenous communities between 2009 and 2014 (2009, $n=7$, and 2014, $n=94$ ). This increase was made possible by the implementation of memo 058 of 2009 (29) and the subsequent publication of the strategic plan "Colombia Free of Tuberculosis, 2010-2015" (30), which established actions against tuberculosis among indigenous peoples. However, the country must strengthen the dissemination of public policies and ensure its compliance. In this case, all respiratory symptomatic individuals belonging to indigenous peoples should undergo more sensitive laboratory tests, such as those based on DNA amplification, culture, and drug sensitivity tests.

Regarding the presence of tuberculosis cases among indigenous groups, the highest number was registered among the Wayúu people whose groups inhabit La Guajira peninsula and share territory with Venezuela, which means there is a continuous passage between the reservations of both countries. In addition to the geographical conditions of the area, other conditions such as the lack of permanent access to drinking water supply contribute to malnutrition and, therefore, to infectious diseases $(31,32)$.

The indigenous group with the second highest number of tuberculosis cases was the Emberá Chamí, which is primarily located in the Colombian coffee-growing region, whose beliefs about the disease have a spiritual origin and where transmission occurs by settlers. In such a context, the treatment is dictated by the shamans. Although the group also resorts to modern medicine, this approach could explain why this area is the second most affected by the disease (17).

The indigenous group with the third highest number of tuberculosis cases was the Awá. This Amerindian group living in the border between Colombia and Ecuador is one of the most vulnerable populations in Colombia (16). Their main settlements are located in the municipalities of Ricaurte, Tumaco, and Barbacoas in the department of Nariño. Little is known about their traditions because they do not allow their culture to be known. Glyphosate fumigations and invasion of their lands by illegal armed groups may have resulted in poverty, shortage of foods of animal origin, and low soil fertility, which have impacted their health conditions (31-33).

The number of tuberculosis cases was similar in women and men contrasting with global reports in which men were the most affected by the disease (2). This difference may be related to deficiencies in the treatment of index cases, late diagnosis, and social factors such as "machismo", as in these groups men decide whether women can go to health care centers when they are sick (34), as well as to women's low education level hindering them from participating in decision-making, thus making access to diagnosis and timely care difficult (35), and child care, which also limits women's access to healthcare services. This situation calls for reinforcing prevention, diagnosis, monitoring, and control programs in families to prevent transmission, especially from mothers affected by the disease to underage children.

Regarding age, the group most affected by tuberculosis was between 15 and 29 years. The younger and older age groups had fewer cases. This situation coincided with previous studies conducted by Culqui, et al., whose study on tuberculosis among indigenous peoples from Perú reported that $78.6 \%$ of the cases occurred in people of productive age (adolescents and adults), $2.5 \%$ in children and infants, and $7 \%$ in older adults (12). This distribution may be explained by the displacement that indigenous peoples in productive age are 
forced to for food or resources, which means they have contact with nonindigenous people and, therefore, with different types of diseases (36).

As regards bacilloscopy, $42.7 \%$ of the individuals had $\geq++$ results indicating a late diagnosis, which can reflect health care access difficulties and answer to the dispersion of communities and the lack of knowledge about the disease among other factors (31). Studies conducted by Ribeiro, et al., and Gaviria, et al., $(37,38)$ found a relation between late tuberculosis diagnosis and disease-associated social stigma, as well as insufficient knowledge of health professionals regarding the identification of respiratory symptoms in a timely manner.

The proportion of multidrug resistant isolates cannot be compared with that found worldwide or in national annual reports. According to WHO (2), multidrug resistance is expected in 3.3\% of new cases. In 2007 in Colombia, 3.2\% of new tuberculosis cases in the general population were multidrug resistant tuberculosis while in tuberculosis previously treated cases it was $20 \%$. Any number of cases is indicative of the failure of treatment, the transmission of primary drug-resistant strains, and lack of adherence and follow-up. The presence of resistant isolates in a vulnerable population such as the indigenous populations should prompt the implementation of programmatic actions to control tuberculosis sensitivity and develop shorter, less toxic, and more effective treatment regimens to avoid second-line treatments.

Since tuberculosis control and eradication are closely linked to the knowledge about the disease, the social, cultural, economic, and biological aspects contributing to the persistence of the bacillus in the community must be elucidated. In this setting, molecular epidemiology has positioned itself as a useful tool for the study of transmission dynamics by implementing techniques such as spoligotyping (39).

In this study, the genetic families most frequently found by spoligotyping among indigenous peoples were in descendent order LAM, Haarlem, and T, a finding consistent with previous reports for the Colombian population (22-27). However, the high number of orphan spoligotypes recorded is of particular interest for public health. Another important consideration is the presence in the municipality of Buenaventura of the Beijing family due to its virulence, strong association with multidrug resistance, and extensive drug resistance $(24,26,27,40-42)$.

Buenaventura is the most important port in Colombia and probably it was the gateway of this genotype from Asia into the country. Our results confirmed a new Beijing spoligotype (Beijing-like SIT 406) circulating in Colombia; this is the second report of this spoligotype in Latin America (43). The specific location was Tumaco.

The 14 spoligotypes we identified by spoligotyping that had not been previously reported in Colombia were the following: [LAM2 SIT 1691, T2 SIT 52, H3 SIT 418, H3 SIT 615, LAM 6 SIT 1768, LAM9 SIT 1074, LAM9 SIT 1530, S SIT 1253, S SIT 1938, T1 SIT 278, T1 SIT 628, T1 (Tuscany variant) SIT 159, U SIT 1451, and Beijing-like SIT 406], as well as 51 orphan spoligotypes without prior descriptions in the international SpolDB4 database nor in national studies (22-27). These spoligotypes could be circulating exclusively among the indigenous populations, which calls for more in-depth studies. Only three of the orphan patterns identified in the indigenous Risaralda and Putumayo groups had previously been described in Colombia circulating in the departments of 
Putumayo, Cauca, and in Bogotá (23-24). The presence of these spoligotypes among indigenous populations most likely responds to social factors such as the armed conflict and the search for a better quality of life, which has generated a migratory process to different places in the country (44).

According to the similarity dendrogram, $69.2 \%$ of the spoligotypes were clustered suggesting active tuberculosis transmission, especially among the Wayúu, Emberá Chamí, U'wa, and Awá groups. The use of spoligotyping as the sole genotyping method results in low discriminatory power; therefore, the frequency of transmission was most likely overestimated. However, the spoligotyping discrimination index in this study (0.963) should be considered because it indicates discrimination between unrelated isolates, which was close to 1.0 , i.e., higher (28).

Although one of the limitations of this study was the low number of isolates analyzed, it is the first at the national level to characterize a large number of isolates from Colombian indigenous populations and the first approach to $M$. tuberculosis circulating genotypes. Our results provide partial evidence of the actual situation of tuberculosis among Colombian indigenous peoples, which can serve decision-makers in taking actions aimed at putting an end to the tuberculosis epidemic as set out in WHO global guidelines for 2035 (2). However, molecular analyses should be done using MIRU-VNTR or Whole Genome Sequencing methodologies to increase the discriminatory power and provide insights into the actual situation of tuberculosis transmission among indigenous peoples in Colombia.

\section{Acknowledgements}

To Colciencias and to the Instituto Nacional de Salud for their help in the development of the project and to the participating territorial entities.

\section{References}

1. Organización de Naciones Unidas. Objetivos de Desarrollo Sostenible. Accessed on: February 25, 2017. Available from: http://www.un.org/sustainabledevelopment/es/objetivosde-desarrollo-sosten

2. World Health Organization. Global Tuberculosis Report, 2017. Accessed on: December 3, 2017. Available from: https://reliefweb.int/sites/reliefweb.int/files/resources/9789241565516-eng.pdf

3. Instituto Nacional de Salud. Informe de Evento Tuberculosis, Colombia -2016. Accessed on: September 5, 2017. Available from: http://www.ins.gov.co/lineas-de-accion/SubdireccionVigilancia/Informe\%20de\%20Evento\%20Epidemiolgico/TUBERCULOSIS\%20\%202016.pdf

4. World Health Organization. Proyecto de estrategia mundial y metas para la prevención la atención y el control de la tuberculosis después de 2015, 67ª Asamblea Mundial de la Salud. Accessed from: March 5, 2017. Available on: http://apps. who.int/gb/ebwha/pdf files/ WHA67-REC1/A67_2014_REC1sp.pdf

5. Stephens C, Porter J, Nettleton C, Willis R. Disappearing, displaced, and undervalued: A call to action for Indigenous health worldwide. Lancet. 2006;367:2019-28.

https://doi.org/10.1016/S0140-6736(06)68892-2

6. Cardona JA, Hernández AM. Conocimientos, actitudes y prácticas sobre tuberculosis en indígenas zenúes y habitantes de una zona rural colombiana. Rev Cienc Salud. 2013;11:157-71.

7. Barros D, Costa R, de Albuquerque B, Sadahiro M, Ueleres J. The socioeconomic factors and the indigenous component of tuberculosis in Amazonas. PLoS One. 2016;6:1-10. https://doi.org/10.1371/journal.pone.0158574

8. Ministerio de Cultura de Colombia. Caracterización y situación actual de los pueblos indígenas. Accessed on: February 10, 2017. Available from: https://www.unicef.org/ colombia/pdf/pueblos-indigenas.pdf 
9. Departamento Nacional de Estadística. Colombia una Nación Multicultural: Su diversidad étnica - 2007. Accessed on: March 5, 2017. Available from: http://www.dane.gov.co/files/ censo2005/etnia/sys/colombia_nacion.pdf

10. Medel B, Castellanos M, García M, Martínez R, Decroo T, Zachariah R. Tuberculosis among indigenous municipalities in Mexico: Analysis of case notification and treatment outcomes between 2009 and 2013. Rev Panam Salud Pública. 2016;39:32-7.

11. Cermeño J, Súnico L, Cermeño V, Julmery J, Godoy G, Hernández de Cuesta I, et al. Tuberculosis y micosis sistémicas en indígenas del Municipio Cedeño, Estado Bolívar, Venezuela. Med Interna Caracas. 2013;29:62-7.

12. Culqui D, Zabaleta C, Romero J, Bonilla C, Trujillo O, Cueva N. Tuberculosis en poblaciones indígenas del Perú: los aimaras del Perú, 2000-2005. Rev Peru Epidemiol. 2009;13:1-6.

13. Malacarne J, Giraldo D, Furtado C, Ueleres J, Bastos L, Basta P. Prevalence and factors associated with latent tuberculosis infection in an indigenous population in the Brazilian Amazon. Rev Soc Bras Med Trop. 2016; 49(4): 456-464. https://doi.org/10.1590/0037-8682-0220-2016

14. Tollefson D, Bloss E, Fanning A, Redd JT, Barker K, McCray E. Burden of tuberculosis in indigenous peoples globally: A systematic review. Int J Tuber Lung Dis. 2013;17:1139-50. https://doi.org/10.5588/ijtld.12.0385

15. Cunha EA, Ferrazoli L, Riley LW, Basta PC, Honer MR, Maia R, et al. Incidence and transmission patterns of tuberculosis among indigenous populations in Brazil. Mem Inst Oswaldo Cruz. 2014;109:108-13. https://doi.org//10.1590/0074-0276130082

16. Ministerio de la Protección Social - Instituto Nacional de Salud, Agencia Canadiense para el Desarrollo Internacional, Organización Panamericana de la Salud, Organización Mundial de la Salud. Tuberculosis en los pueblos indígenas de Colombia: el reto de la prevención y el control. Accessed on: March 5, 2018. Bogotá: Organización Panamericana de la Salud; 2007. p. 86.

17. Hernández J, Dávila V, Martínez L, Restrepo L, Grajales N, Toro A, et al. Tuberculosis in indigenous communities of Antioquia, Colombia: Epidemiology and beliefs. J Immigrant Minority Health. 2013;15:10-6. https://doi.org/10.1007/s10903-012-9688-1

18. García de Viedmaa D, Mokrousovc I, Rastogi N. Innovations in the molecular epidemiology of tuberculosis. Enferm Infecc Microbiol Clin. 2011;29(Supl.1):8-13.

https://doi.org/10.1016/S0213-005X(11)70012-X

19. van Soolingen $D$, de Haas PE, Kremer K. restriction fragment length polymorphism typing of mycobacteria. In: Parish T, Stoker NG, editors. Mycobacterium tuberculosis protocols. Methods in molecular medicine. New Jersey: Humana Press; 2001. p.165-203.

20. Kamerbeek J, Schoulds L, Kolk A, Van-agterveld M, Van-Sooligen D, Kuijper S, et al. Simultaneous detection and strain differentiation of Mycobacterium tuberculosis for diagnosis and epidemiology. J Clin Microbiol. 1997;35:907-14.

21. Brudey K, Driscoll J, Rigouts L, Prodinger W, Gori A, Al-Hajoj S, et al. Mycobacterium tuberculosis complex genetic diversity: Mining the fourth international spoligotyping database (SpolDB4) for classification, population genetics and epidemiology. BMC Microbiol. 2006;61-17. https://doi.org/10.1186/1471-2180-6-23

22. Castro C, Ricardo A, Zabaleta A, Llerena C, Puerto G. Characterization of clinical isolates of Mycobacterium tuberculosis from HIV positive individuals in Colombia, 2012. Biomédica. 2017;37:86-95. https://doi.org/10.7705/biomedica.v37i1.3112

23. Realpe T, Correa N, Rozo J, Ferro B, Gómez V, Zapata E, et al. Population structure among Mycobacterium tuberculosis isolates from pulmonary tuberculosis patients in Colombia. Plos One. 2014;109:1-12. https://doi.org/10.1371/journal.pone.0093848

24. Puerto G, Erazo L, Wintaco M, Castro C, Ribón W, Guerrero M. Mycobacterium tuberculosis genotypes determined by spoligotyping to be circulating in Colombia between 1999 and 2012 and their possible associations with transmission and susceptibility to first-line drugs. Plos One. 2015;10:1-14. https://doi.org/10.1371/journal.pone.0124308

25. Cerezo I, Jiménez Y, Hernández J, Zozio T, Murcia M, Rastogi N. A first insight on the population structure of Mycobacterium tuberculosis complex as studied by spoligotyping and MIRU-VNTRs in Bogotá, Colombia. Infect Genet Evol. 2012;12:657-63. https://doi.org/10.1016/j.meegid.2011.07.006

26. Nieto L, Ferro B, Villegas S, Mehaffy C, Forero L, Moreira C, et al. Characterization of extensively drug-resistant tuberculosis cases from Valle del Cauca, Colombia. J Clin Microbiol. 2012;50:4185-7. https://doi.org//10.1128/JCM.01946-12 
27. Ferro B, Nieto L, Rozo J, Forero L, van Soolingen D. Multidrug-resistant Mycobacterium tuberculosis, Southwestern Colombia. Emerg Infect Dis. 2011;17:1259-62. https://doi.org/10.3201/eid1707.101797

28. Hunter PR, Gaston MA. Numerical index of the discriminatory ability of typing systems: An application of Simpson's index of diversity. J Clin Microbiol. 1998;26:2465-6.

29. Ministerio de Salud y Protección Social. Circular 058 de 2009: Lineamientos para el manejo programático de tuberculosis y lepra. Accessed on: March 5, 2018. Available from: https:// www.minsalud.gov.co/sites/rid/Lists/BibliotecaDigital/RIDE/DE/D/J/circular-externa-0007de-2015.pdf

30. Ministerio de Salud y Protección Social. Plan Estratégico Colombia Libre de Tuberculosis 2010-2015: Para la Expansión y Fortalecimiento de la Estrategia Alto a la TB. Bogotá D.C: 2009. p. 64. Accessed on: April 5, 2018. Available from: https://www.minsalud.gov.co/sites/ rid/Lists/BibliotecaDigital/RIDE/VS/PP/ET/plan-monitoreo-evaluacion-tuberculosis.pdf

31. Li Y, Ehiri J, Tang S, Li D, Bian Y, Lin H, et al. Factors associated with patient, and diagnostic delays in Chinese TB patients: A systematic review and meta-analysis. BMC Med. 2013;11:156. https://doi.org/10.1186/1741-7015-11-156

32. Bisbicús G, Paí J, Paí, R. Comunicación con los espíritus de la naturaleza para la cacería, pesca, protección, siembra y cosecha en el pueblo indígena Awá de Nariño. Bogotá D.C: Programa Somos Defensores; 2010. p. 90. Accessed on: March 21, 2018. Available from: http://www.onic.org.co/documentos/1467-comunicacion-con-los-espiritus-de-la-naturalezapara-la-caceria-pesca-proteccion-siembra-y-cosecha-en-el-pueblo-indigena-awa-de-narino

33. Programa de las Naciones Unidas para el Desarrollo. Pueblos indígenas. Diálogo entre culturas. Cuaderno del Informe de Desarrollo Humano de Colombia. Bogotá: PNUD; 2012. p. 96. Accessed on: March 30, 2018. Available from: http://www.co.undp.org/content/colombial es/home/library/human development/pueblos-indi genas---dialogo-entre-culturas.html

34. Sieder R, Sierra M. Indigenous women's access to justice in Latin America. CMI Working Paper WP; 2010. Accessed on: September 22, 2017. Available from: https:/www.cmi.no/ publications/3880-indigenous-womens-access-to-justice-in-latin

35. Oshi D, Oshi S, Alobu I, Ukwaja K. Gender-related factors influencing women's health seeking for tuberculosis care in Ebonyi State, Nigeria. J Biosoc Sci. 2016;48:37-50. https://doi.org/10.1017/S0021932014000534

36. UNICEF. Los pueblos indígenas en Colombia: derechos, políticas y desafíos. Bogotá D.C: UNICEF; 2009. p. 91. Accessed on: September 5, 2017. Available from: https://www.unicef. org/colombia/pdf/pueblos-indigenas.pdf

37. Ribeiro M, Dalla I, Silva S. Factores asociados el diagnóstico precoz y tardío de la tuberculosis: estudio descriptivo. Online Braz J Nurs. 2014;13:62-71.

38. Gaviria M, Henao H, Martínez T, Bernal E. Papel del personal de salud en el diagnóstico tardío de la tuberculosis pulmonar en adultos de Medellín, Colombia. Rev Panam Salud Pública. 2010;27:83-92.

39. Dorronsoro I, Torroba I. Microbiología de la tuberculosis. Anales Sis San Navarra. 2007;30(Supl. 2):67-85

40. Chen Y, Chang J, Huang W, Kuo S, Yeh J, Lee J, et al. Molecular epidemiology of Mycobacterium tuberculosis in aboriginal peoples of Taiwan, 2006 -2011. J Infect. 2014;68:332-7. https://doi.org/10.1016/j.jinf.2013.12.004

41. Álvarez N, Haft D, Hurtado UA, Robledo J, Rouzaud F. Whole-genome sequence of a Beijing extensively drug-resistant Mycobacterium tuberculosis clinical isolate from Buenaventura, Colombia. Genome Announc. 2016;4:e01549-15. https://doi.org//10.1128/genomeA.01549-15

42. Murcia MI, Manotas M, Jiménez Y, Hernández J, Cerezo I, Cortés MI, et al. First case of multidrug-resistant tuberculosis caused by a rare "Beijing-like". Infect Genet Evol. 2010;10:678-81. https://doi.org/10.1016/j.meegid.2010.03.010

43. Flores S, Morfín R, Rodríguez E, González E, Pérez H, Bocanegra V, et al. Genetic diversity of Mycobacterium tuberculosis from Guadalajara, Mexico and identification of a rare multidrug resistant Beijing genotype. PLoS One. 2015;10:1-11. https://doi.org/10.1371/ journal.pone.0118095

44. Idrovo A. Raíces históricas, sociales y epidemiológicas de la tuberculosis en Bogotá, Colombia. Biomédica. 2004;24356-65. https://doi.org/10.7705/biomedica.v24i4.1285 
Supplementary table 1. Distribution of orphan patterns identified by spoligotyping in the study

\begin{tabular}{|c|c|c|c|c|}
\hline Spoligotype & Binary Spoligotype & Octal & $\mathbf{n}$ & $\%$ \\
\hline Orphan $1^{*}$ & 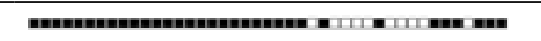 & 777777775020731 & 9 & 3.85 \\
\hline Orphan $2^{*}$ & 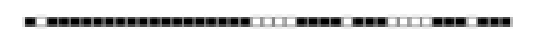 & 577777607560731 & 3 & 1.28 \\
\hline Orphan $3^{*}$ & 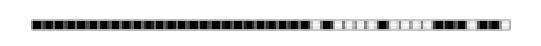 & 777777775020730 & 3 & 1.28 \\
\hline Orphan 4 & 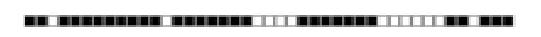 & 677737607740331 & 2 & 0.85 \\
\hline Orphan 5 & 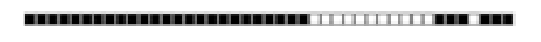 & 777777774000731 & 2 & 0.85 \\
\hline Orphan 6 & 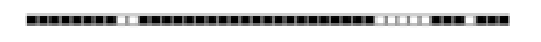 & 776377777740731 & 2 & 0.85 \\
\hline Orphan 7 & 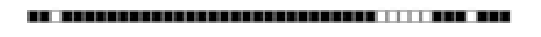 & 737777777740731 & 2 & 0.85 \\
\hline Orphan 8 & 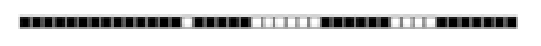 & 777767601760771 & 1 & 0.43 \\
\hline Orphan 9 & 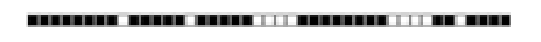 & 776767607760671 & 1 & 0.43 \\
\hline Orphan 10 & 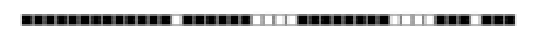 & 777757607760731 & 1 & 0.43 \\
\hline Orphan 11 & 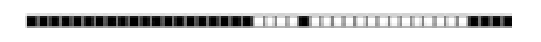 & 777777604000071 & 1 & 0.43 \\
\hline Orphan 12 & 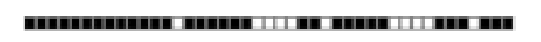 & 777757606760731 & 1 & 0.43 \\
\hline Orphan 13 & 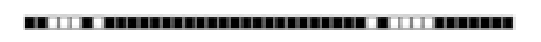 & 613777777720771 & 1 & 0.43 \\
\hline Orphan 14 & 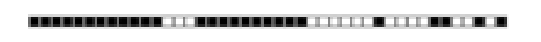 & 777707774020621 & 1 & 0.43 \\
\hline Orphan 15 & 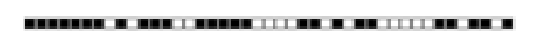 & 775347606540661 & 1 & 0.43 \\
\hline Orphan 16 & 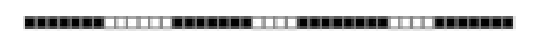 & 774037607760771 & 1 & 0.43 \\
\hline Orphan 17 & 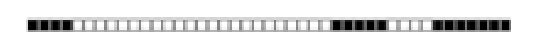 & 740000000760771 & 1 & 0.43 \\
\hline Orphan 18 & 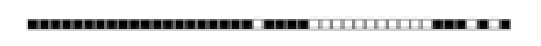 & 777777674020721 & 1 & 0.43 \\
\hline Orphan 19 & 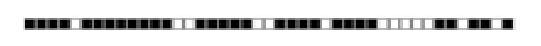 & 757747636740661 & 1 & 0.43 \\
\hline Orphan 20 & 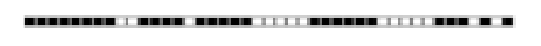 & 776367603740721 & 1 & 0.43 \\
\hline Orphan 21 & 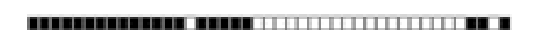 & 777767600000061 & 1 & 0.43 \\
\hline Orphan 22 & - & 777775607760771 & 1 & 0.43 \\
\hline Orphan 23 & 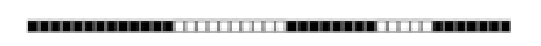 & 777736777740771 & 1 & 0.43 \\
\hline Orphan 24 & 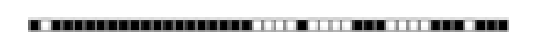 & 577777604160731 & 1 & 0.43 \\
\hline Orphan 25 & 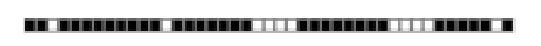 & 677737607760761 & 1 & 0.43 \\
\hline Orphan 26 & 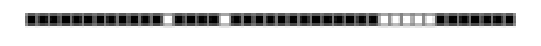 & 777777674020731 & 1 & 0.43 \\
\hline Orphan 27 & 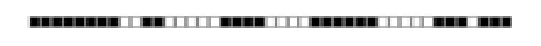 & 776301703740731 & 1 & 0.43 \\
\hline Orphan 28 & 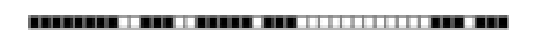 & 776347670000731 & 1 & 0.43 \\
\hline Orphan 29 & 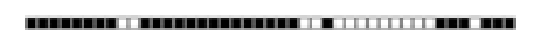 & 776377771000731 & 1 & 0.43 \\
\hline Orphan 30 & 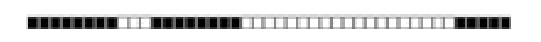 & 776077600000171 & 1 & 0.43 \\
\hline Orphan 31 & 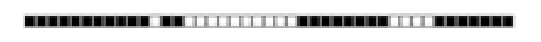 & 777660007760771 & 1 & 0.43 \\
\hline Orphan 32 & 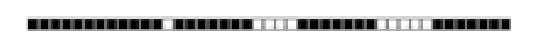 & 777737607740771 & 1 & 0.43 \\
\hline Orphan 33 & 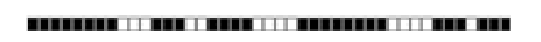 & 776163607760731 & 1 & 0.43 \\
\hline Orphan 34 & 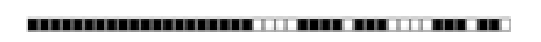 & 777777607560730 & 1 & 0.43 \\
\hline Orphan 35 & 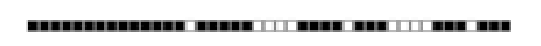 & 777767607560731 & 1 & 0.43 \\
\hline Orphan 36 & 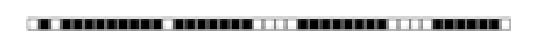 & 277737607760770 & 1 & 0.43 \\
\hline Orphan 37 & 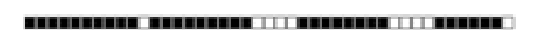 & 777577607760770 & 1 & 0.43 \\
\hline Orphan 38 & 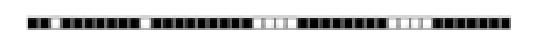 & 677577607760771 & 1 & 0.43 \\
\hline Orphan 39 & 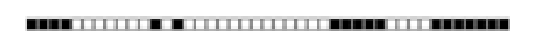 & 740120000760771 & 1 & 0.43 \\
\hline Orphan 40 & 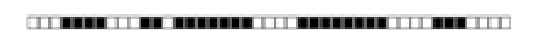 & 074337607760700 & 1 & 0.43 \\
\hline Orphan 41 & 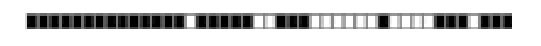 & 777767634020731 & 1 & 0.43 \\
\hline Orphan 42 & 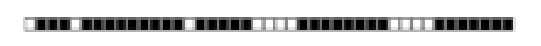 & 357767607760771 & 1 & 0.43 \\
\hline Orphan 43 & 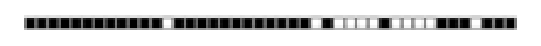 & 777737775020731 & 1 & 0.43 \\
\hline Orphan 44 & 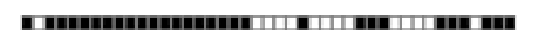 & 577777604160771 & 1 & 0.43 \\
\hline Orphan 45 & 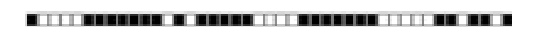 & 417727607740661 & 1 & 0.43 \\
\hline Orphan 46 & 10 & 077777607760411 & 1 & 0.43 \\
\hline Orphan 47 & 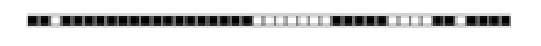 & 677777600760671 & 1 & 0.43 \\
\hline Orphan 48 & 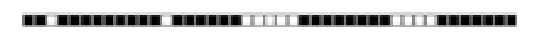 & 677737407760771 & 1 & 0.43 \\
\hline Orphan 49 & 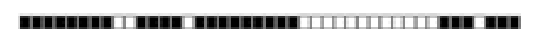 & 776367770000731 & 1 & 0.43 \\
\hline Orphan 50 & 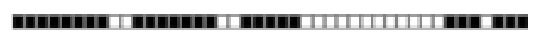 & 776376370000731 & 1 & 0.43 \\
\hline Orphan 51 & 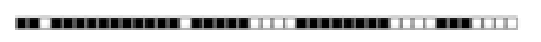 & 677767607760700 & 1 & 0.43 \\
\hline Orphan 52 & 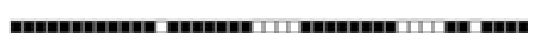 & 777737607760671 & 1 & 0.43 \\
\hline Orphan 53 & 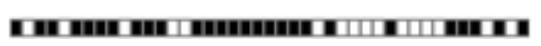 & 557347775020721 & 1 & 0.43 \\
\hline Orphan 54 & 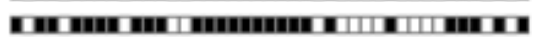 & 777765607760661 & 1 & 0.43 \\
\hline
\end{tabular}


Puerto D, Erazo LM, Zabaleta A, et al.

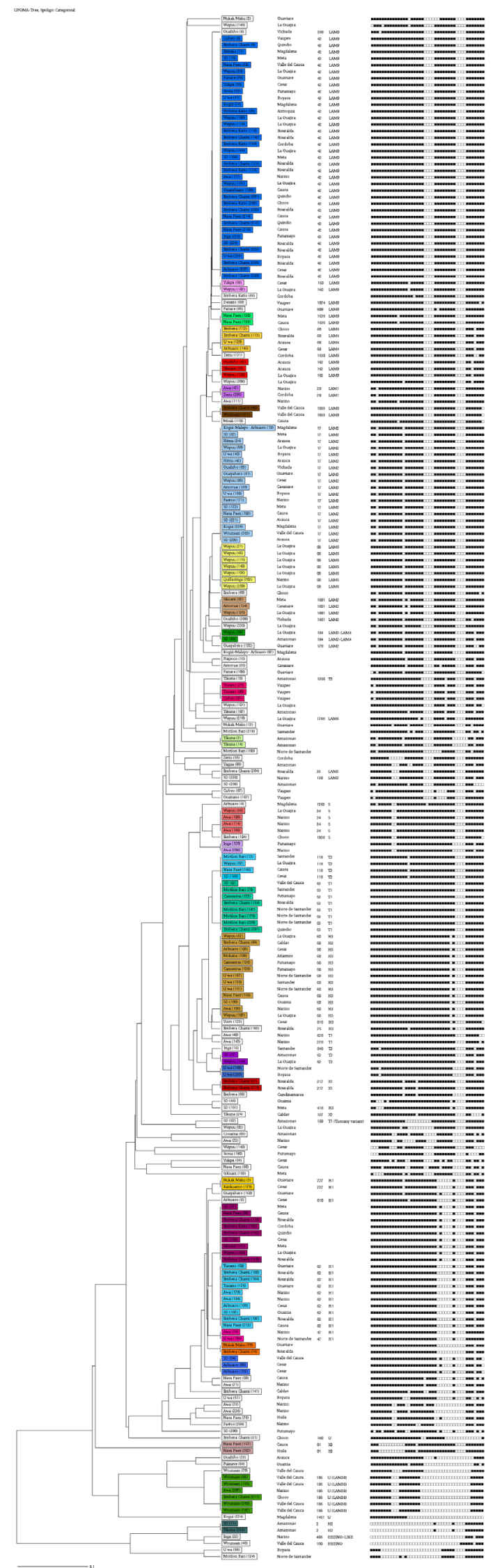

Supplementary figure 1. Similarity dendrogram using the spoligotyping methodology 